\title{
The West Coast as a Literary Capital: Independent Publishers as a Contumacious Canon of Underground Poetry
}

La côte Ouest comme capitale littéraire: les éditeurs indépendants, vecteurs

d'un canon irrévérent de la poésie 'underground'

La costa Oeste como capital literaria: los editores independientes, agentes de un canon irreverente de la poesía 'underground'

\section{William Mohr}

\section{(2) OpenEdition}

\section{Journals}

Electronic version

URL: https://journals.openedition.org/ideas/2447

DOI: 10.4000/ideas.2447

ISSN: 1950-5701

\section{Publisher}

Institut des Amériques

\section{Electronic reference}

William Mohr, "The West Coast as a Literary Capital: Independent Publishers as a Contumacious Canon of Underground Poetry", IdeAs [Online], 11 | 2018, Online since 15 June 2018, connection on 18 October 2022. URL: http://journals.openedition.org/ideas/2447 ; DOI: https://doi.org/10.4000/ideas. 2447

This text was automatically generated on 18 October 2022.

\section{cc) (†)}

Creative Commons - Attribution-NonCommercial-NoDerivatives 4.0 International - CC BY-NC-ND 4.0 https://creativecommons.org/licenses/by-nc-nd/4.0/ 


\title{
The West Coast as a Literary Capital: Independent Publishers as a Contumacious Canon of Underground Poetry
}

\author{
La côte Ouest comme capitale littéraire : les éditeurs indépendants, vecteurs \\ d'un canon irrévérent de la poésie 'underground' \\ La costa Oeste como capital literaria: los editores independientes, agentes de un \\ canon irreverente de la poesía 'underground'
}

William Mohr

1 The overarching concern of the "Modernities in the Americas" conference reflected a recent shift in the field of Literature from "modernity" as a singular, though exceptionally capacious, paradigm to a plurality of synchronic invocations; although this expansion has intrigued many critics and led them to revisit basic assumptions, it has also led them all too often to critical rubrics no different from when modernity's tunneling was configured as a unique labyrinth. Among those in the past four decades who have addressed the crisis of the plural metanarrative is Susan Stanford Friedman, who defines modernity in a dialectal manner, as that which "has a complex and contradictory relationship to its seeming opposite - 'tradition' or 'history.' Modernity and tradition," Friedman insists, are "relational concepts that modernity produces to cut itself off from the past, to distinguish the 'now' from the 'then' " (Friedman, Planetary Modernism, 156). Furthermore, she argues, the synthesis of this cauterizing dialectic contains an empowering helix of simultaneous programs: "modernity invents tradition, suppresses its own continuities with the past, and often produces nostalgia for what has been seemingly lost" (PM, 156). ${ }^{1}$ As influential as these notions have been in shaping the critical environment that has led to this conference, this configuration of modernity does not lead to a complete overhaul of the methods used to examine literature. In point of fact, when one reads her article, the usual and predictable move takes place: from a theoretical context, one moves on to the discussion of the central 
texts, which in that instance prove to feature books many of us will be familiar with, including that classic of Third World exile, Season of Migration to the North. Authorial privileging does not in the least blink.

In place of the habit by which critics of modernity privilege authors, I would suggest that we instead reconsider the implications of Robert Darnton's communications circuit. If we study this chart's almost tangential juxtaposition of the author and publisher in equally large, filled-in rectangles, we will see that a leveling of cultural significance takes place that is perhaps even more radical than the discourse in which literary criticism takes its place, at least within the academy, as being every bit as creative, imaginative and worthy of canonical approbation as writing produced by novelists or poets or playwrights. Although exceptionally useful as a compass sketch to establish basic choreographic circulation, one basic problem with Darnton's description is the assumption that the publisher does not constitute a reader. ${ }^{2}$ Darnton effectively consigns the publisher to the role of some kind of electrical transformer. The author is the generator of electricity, so to speak, and in Darnton's analysis, the publisher is really nothing more than high-tension wires conveying that energy to the porous transparency of the reader's well-lit imagination. That the publisher is the sine qua non reader who more frequently than not ends up altering the text in significant ways seems to be totally ignored in Darnton's configuration.

Darnton's chart unflinchingly sets publishers and authors alongside each other as coevals, and the consequences of this equation have yet to be sufficiently acknowledged within discussions of modernity. Consider, for instance, the bibliographic citation in the footnote for Friedman's discussion of Season of Migration to the North: Boulder, Colorado: Three Continents Press. If, indeed, Darnton's configuration were taken as seriously as it needs to be taken, then at the very minimum the footnote would go on at some length, and provide a vigorous reminder of Roger Chartier's admonishment: “Authors do not write books not even their own books. Books be they manuscript or printed, are always the result of multiple operations that suppose a broad variety of decisions, techniques, and skills" (Chartier, Authors Hand 150). Nor, should it be added, do publishers write books. It is the polycentric convergence of the publisher-author-printer that brings the book into the wide (rippling) swath of circulation that all who have contributed to its existence imagine as a possibility. Yet having been generous in declaring an equivalency, I would now declare the heresy: it is publishers who can best serve as the core of the index called for by Pascale Casanova in World Republic of Literature, if only to discover the aftershocks and full repercussions of such a radical synchronic arrangement:

"What is needed, then, is an index or measure of literary authority that can account for the linguistic struggles in which all contestants in the game of literature take part without even knowing it, by virtue simply of belonging to such a linguistic area, and clearly the mediating role of texts and translations, the making and breaking of reputations, and the process of literary consecration and excommunication (20).

One aspect of using this category as a way of indexing authority is that it offers the possibility of a juxtaposition capable of slightly neutralizing the hierarchies. If one were to generate a chronological sequence of publishers, one would be able to take advantage of the one thing that no one in canonical discourse ever seems to mention, which is to say that no one ever bemoans the lack of a singular, dominating publisher. One overhears the nostalgic yearning for a period in which a handful of figures 
dominated the literary landscape like benevolent dictators ("The Age of Pope"; "The Age of Auden"; "The Age of Lowell"), but one never hears complaints for the "good old days" in which a single publisher had vanquished any serious competition. Obviously, no such situation existed, and despite the absorption of many old publishing firms into corporate behemoths, there is no evidence in the still feisty enclaves of print culture that a single company towers over all the others. If anything, the counterattack of ever more small, independent presses has been revitalized in recent years, in particular on the West Coast of the United States.

5 In this paper, therefore, I wish to consider publishers to be one of the primary agents in the social life of various "modernities," and to regard their simultaneous efforts as an essential conjuncture within an empowering diaspora of cultural authority. Instead of being a minimalistic notation in a critical footnote, or the economic nexus for a book distributor, publishers must have their full lists in the foreground, so that the internal dialogue of the themes of their clustered titles is paramount, and is consequently able to amplify the external comparison. The juxtaposition of the publishing lists of various enterprises would allow us to observe the actual formation of islands of authorial identity, which is never formed only from the peculiar style of a writer, but is an accretion that depends wholly on the context the writing finds itself embedded within. If each publishing house is a volcano, then the lava is the immense outpouring of words that slowly cools and allows the reader to take up residence and prosper on this renewed soil.

The typical effacement of the publisher's role - a role often configured as merely a matter of mechanical reproduction - is all too easy to find instances of. "Once published, the literary work ceases to belong to the writer to become the property of the reader" (Peden, Fuentes Decalogue 80). The "once published" phrase, in all its presumptuous brevity, betrays the lackadaisical understanding of the process by the cultural critic. It has all the condescension of someone saying about a month-old infant, "Once born," as if pregnancy and parturition were afterthoughts to be discarded like a disposable diaper. In contrast, I would argue, above all, let us remember that the publisher is a reader; in fact, the first and most important reader, the one who serves as the muse of criticism. Perhaps the reluctance to press on this issue might be excused out of the fear that publishers might begin to negotiate for more cultural credit for their work, beyond that of being the reader of that which has not yet been read by anyone without the power to bestow cultural largesse, and that this credit would extend into, envelope, and absorb the realm of authorship. Most certainly there are publishers who deep in their editorial hearts believe that they deserve to be acknowledged as co-creators, and the incommensurate fact is that they are right. Nevertheless it is unlikely that many people are going to endorse Alan Swallow's claim, for instance, that Frank Waters's most famous novel The Man who Killed the Deer should be accounted "darned near as much my book as Frank's" (Nelson, Imprint 121). It must be said that no matter how many similar claims might be made, all such evidence put together would do no more, however, than simply distract from much more important assessments.

7 Although the period of the conference is 1910-1970, I am focusing on the last decades of that swing of modernity's pendulum as we consider the actual social spaces on the West Coast of the United States that contributed to a period of cultural turbulence I have categorized as hyper-modernity. Before we narrow down to the quarter-century 
chronotope of West Coast writing in the United States between 1945 and 1970, however, let us pull back for a minute and consider a different stage of human development and how our assessment of that cultural work might apply to our present concerns. If one were to consider the development of ceramics and pottery in specific parts of the "ancient world," one could probably find example of practices that were idiosyncratic to a very limited territory, but one would find it much more likely and advantageous to consider how so-called local practices would actually spread out over several hundred miles. This is to say that if in any given century three or four millennia ago we were to find certain consistent designs of kilns in an area that bordered a substantial coastline and certain patterns in the fired clay of pots and jars, we would not be caught off guard and marvel at the peculiarity of these large clusters of overlapping populations. In a similar manner, the poetics of production on the West coast in the decades after World War II suggests that a very substantial region served as a comprehensive site of cultural export. As popular as some enabling local fictions are, we should not be surprised by how illusory certain perceptions of recent American poetry might prove to be. The notion, for instance, that there is far less substantial difference between San Francisco on one hand and Los Angeles on the other, in terms of poetry in 1955 might strike some critics as heresy.

8 As I pointed out in my book, Holdouts, the fact remains that more poetry magazines were being published in Los Angeles than in San Francisco during the fifteen years between 1947 and 1962. Now while that fact might surprise many people who think of San Francisco as the poetry capital of "hip" poetry, if not all poetry in the United States at that time, the point of citing that comparative magazine publication is not to pull one city into equivalency but simply to establish the degree of cultural work that was being done along the western coastline. Much of this work was in response to a situation that would be familiar to others elsewhere who find themselves without the cultural capital needed to provide a sense of legitimacy to one's efforts.

The basic problem, in fact, in being able to understand the larger displacements of modernity on the West Coast is that very traditional binaries are still at work in demarcating what is actually a unified field of cultural endeavor. In 2015, Cambridge University Press published a volume entitled A History of California Literature, which replicates the usual north-south distinctions. Chapter 16, which is fourteen pages long, devotes itself to "Bay Area Poetics, 1944-1981", while Chapter 17, almost one-third longer at twenty pages, surveys "Los Angeles Poetry from the McCarthy to the Punk Eras." Appropriately enough for this conference, the second paragraph of the article on the Bay Area does not waste any time in citing Pascale Casanova's suggestion that "literary capitals exist in the world as do political capitals."

Kaplan Page Harris argues that by the middle 1950s, San Francisco was the "top destination, at least for poets of the counterculture," (Allmendinger, History 246) and that it became a nascent literary capital equivalent to Paris, London, and New York. In fact, Harris claims that "in many imaginations... the world's leading avant-garde center." The surveys of both the Bay Area and Los Angeles fail to integrate the common practices that make it one extremely diverse fertile crescent, to borrow a term used to describe one of the earliest regions for the emergence of civilizations. Although Harris cites publishers as an essential factor in the infrastructure of a literary capital, not a single publisher receives a full paragraph, not even Lyn Hejinian's Tuumba Press. Brian 
Kim Stefans is equally neglectful, though one senses his regret at having to compress and exclude several significant small press publishing projects. ${ }^{3}$

The impact of the literary presses in California is precisely what makes this region as a whole the first suburban literary capital, or even perhaps to use a more recent term, an exurban literary capital, in which a region's amplitude becomes a capital intent on leveling cultural hierarchies in the classic antagonism that is the essence of any avantgarde endeavor. ${ }^{4}$

As against the national boundaries that give rise to political belief and nationalist feeling, the world of letters creates its own geography and its own divisions. The territories of literature are defined and delimited according to their aesthetic distance from the place where literary consecration is ordained. The cities where literary resources are concentrated, where they accumulate, become places where belief is incanted, centers of credit, as it were. Indeed, they may be thought of as central banks of a specific sort. ... The emergence and universal recognition of a literary capital, which is to say of a place where literary prestige and belief converge in the highest degree, is a direct result of such belief. The existence of a literary center is therefore twofold: it exists both in the imaginations of those who inhabit it and in the reality of the measurable effects it produces (Casanova, Republic, 23-24).

In thinking, therefore, of the endeavors of West Coast poets and publishers between 1948 and 1980, one needs to keep in mind how the shared assumptions about the cultural value of their work as self-consciously independent publishers articulated an agenda within the reproduction of literary social life. ${ }^{5}$ These renitent stances would include the belief in their own authorial worth as the center of the contemporary groundswell of poetry, and that while poets elsewhere could and would most certainly be included in this renaissance, there would be this crucial difference: poets elsewhere belonged within this interstices of this emerging canon of West Coast poets; or at least it must be understood that those poets all along the coastline who primarily identified with independent presses perceived themselves as the axis of a distinct emerging canon, separate from previously adjudicated roll-calls. Perhaps one could be skeptical of this attempt to create a West Coast canon through a blend of predominant work in this region, but let us remember what I just cited to the effect that the imagination has real effects.

In order to facilitate an initial survey of this region's enactment of an independent press-based canon and the subsequent moiety that each of these presses had in that canon's reflection of the forms and pressures of the age, I am including the following chart: ${ }^{6}$ 
Chart

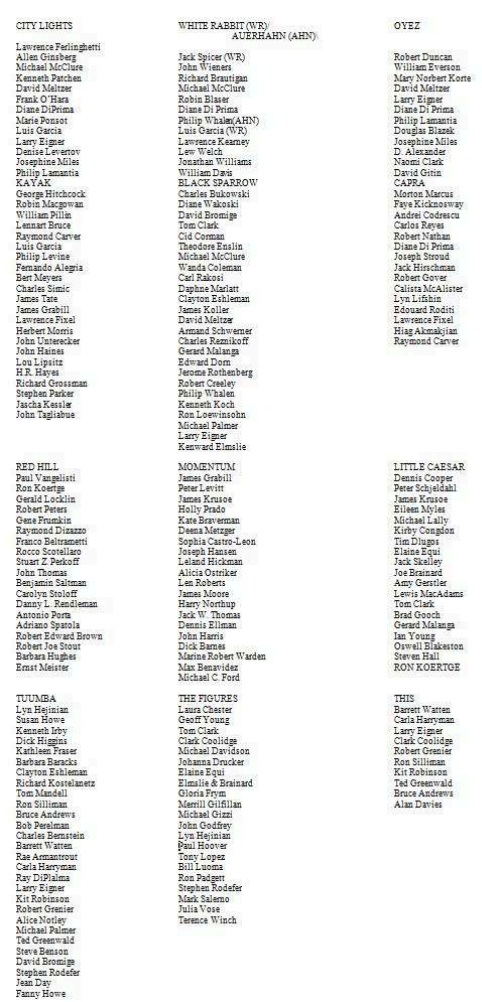

Representing a spectrum of prominent projects by poet-editor-publishers on the West Coast between 1955 and 1985, this chart of a dozen independent presses indicates that the abundance of poetry being written on the West Coast during this period reached far beyond any previous surplus point and required in many instances that writers themselves determine their own roles in exemplifying a literate consciousness. In listing poets who had books published by these ventures, one will note that a majority of these presses were headed up by individuals who went on to achieve distinction as poets themselves. In this regard, the influence of Lawrence Ferlinghetti deserves more than passing acknowledgement. City Lights Bookstore served as the point of conflation for several of the boxes on Darnton's chart, since Ferlinghetti himself was both author, publisher, and distributor of his first collection of poems. The success de scandal of the fourth book published by City Lights, Allen Ginsberg's Howl and Other Poems, proved to be a turning point in making independent publishing on the West Coast a feasible possibility. a cultural contestation. Ferlinghetti's publishing program was largely indistinguishable from - in fact, almost a subset of - the preferences of Donald Allen, whose anthology of "avant-garde" poets was published in $1960 .{ }^{7}$ New American Poetry featured the work of many poets whose work would be published by either Ferlinghetti or one of the half-dozen independent poetry presses that emerged in Northern California in the decade after Howl was published.

Other combinations on Darnton's chart empowered this movement of independent presses. Capra Press in Santa Barbara, for instance, was founded by a printer, Noel Young, who was inspired by the success of one of his customers, John Martin's Black Sparrow Press. ${ }^{8}$ Young began by publishing Henry Miller, he went on to publish a considerable number of poets as well as books of essays by writers such as Ross MacDonald and Ray Bradbury, in addition to a pair of books by Raymond Carver. Although the above chart cites poets, it is worth noting that Young eventually shifted 
from being a printer on the first floor of his shop to the second floor, where he focused on editing. Indeed, Capra Press largely flourished because Young had an uncanny ability to spot social trends. One of his many non-fiction books provided directions on how to install one's own hot tub, and its success underwrote many other volumes of poetry that barely broke even.

In looking at the above publication lists of a dozen independent presses that focused on poetry in the mid- to late-mid twentieth century, one can see the complexity of this particular excavation: one would not only have to become familiar with the work of each individual author, but consider their writing outside of the usual authorcompared-to-author paradigm. How do these authors together form the editorial poetics of each publishing project, and then how do those poetics (not necessarily the author's poetics) address the particular crisis of modernity as it shifts into a "hyper-“ state, especially as that publishing poetics contributes to the emergence of a so-called "counter-culture"?' Indeed, the reformulation of all this publishing activity to emphasize the publisher provides the precise riposte that critics of these poets believe does not exist. Andrew Ross, for instance, excoriated many of the poets in the above columns, especially those in the top three:

(I)n most of the work of the Beats and Black Mountaineers, modernity - urban, technological, and massively commodified - is passed over entirely for some preindustrial cause or pilloried for its dark Satanic birthright in Capital .... In an age in which the established roles of an avant-garde no longer exist,;... how does the old necessity of producing some kind of oppositional response come into conflict with the new necessity of recognizing or coming to terms with a massive commodification of experience governed by a rationality that increasingly insists that all culture now is mass, or popular culture? (Ross, 365).

The example set by a poet such as Lawrence Ferlinghetti in making an independent press the means of an oppositional response to the corporate production of culture seems to have eluded Ross's notice. (This opposition, in fact, begins before Ferlinghetti; I selected him as a starting point merely because he is the best known early example, and it serves a short paper better to focus on the immediately recognizable. Inferno magazine, founded in Los Angeles by a World War II veteran named Leslie Woolf Hedley, had already begun publishing books in 1951 and had over a half-dozen titles out by the time Ferlinghetti self-published his first book in 1955 $5^{10}$; among the poets published by Hedley in his magazine, Inferno: Lawrence Ferling, who went on to make use of the full-length version of his name.) The chain-reaction of several dozen independent presses, each reinforcing the other's community of readers as well as coming together to gain direct access to the means of production, accumulates over a thirty-year period enough shelffuls of work that one would normally associate with the transmission city status of an incognito literary capital. The extent to which the above chart represents only a small portion of the production that needs to be accounted for in any comprehensive assessment of this renaissance cannot be emphasized enough. There are at least a half-dozen presses and editor-publishers that could justifiably lodge a vociferous public complaint in regards to their absence from these columns. Jack Shoemaker, who began publishing in Santa Barbara in the late 1960s and then either founded or directed the operations of several independent publishing projects in Northern California, is one of the most important contributors to this assemblage; all by himself, he could add another three distinct columns to the above chart. Alongside Jack Shoemaker one would have to include individuals who began largely as editors of anthology-styled magazines, such as Ishmael Reed, an African-American novelist whose 
eponymous publishing house has been active in this century, although he might be best known as an editor for Yardbird Reader, an annual volume that eventually became a magazine in the 1970s.

One aspect that links these dozens of projects is their mutual reliance on being able to do more than simply accept manuscripts and offer their imprint on the title page. The contraction of production labor into the instance of editor-publisher-designertypesetter-paste-up artist marked the viability of many of the above projects. A thorough census of the presses in California that made up the entirety of this legacy would require access to an archive of work-order sheets at places such as the West Coast Print Center and NewComp Graphics Center. In compiling such a list, one would have to cross-reference the collected reviews of critics such as Robert Peters, in whose commentary one can note the prevalence of the presses based between Los Angeles County and the Bay Area. Peters, who was a widely published poet himself, does not ignore the East Coast: books from Atheneum, Doubleday, Random House/Alfred Knopf, and Farrar, Straus and Giroux all receive their due attention, but they are far outweighed by the number of his reviews of books from Fred \& Barney Press, Illuminati Press, Fault Press, Jazz Press, ManRoot Books, Pentagram Press, Poltroon Press, Copper Beech, Common Table Press, Burning Deck, Boa Edition, Hanging Loose Press, Cloud Marauder, and Sea Horse. His attention to small presses at work across the United States made him the single most important book reviewer of independent presses in the 1970 and 1980s. "If culture is conversation," as Gabriel Zaid has postulated, then Robert Peters sits at the head of the retrospective table, and will continue to serve as a major resource for understanding the literary conflicts between the above presses as well as apprehending the primary audience for its initial circulation among communities of readers.

However much the independent press movement may have offered an alternative to corporate culture in the mid- to late-mid twentieth century, one cannot help but notice the male dominance of this subculture. If male poets on the West Coast often felt that there was little chance for their writing to be taken seriously by the networks of institutionally shaped canons of decorous taste on the East Coast, then how little access must women poets on the West Coast have perceived as being responsive to their manual typewriters? Judy Grahn, whose poem "A Woman Is Talking to Death," is scandalously underrepresented in anthologies of contemporary poetry, addressed her situation in bluntly reminding us that she had to self-publish her first book.

With the appearance of The Common Woman Poems, which I published in 1969 in a basement mimeograph machine edition, the Lesbian and all manner of other "exotic" female experiences were placed - literarily speaking - in a framework of commonality and the center of females experience. "The common woman is as common as good bread, and will rise," the poems ended and they were quoted and sloganized over a million times in media that ranged from television to T-shirts." Judy Grahn Reader, 272

Conflating the necessity of self-publication by a radical Lesbian poet with the appropriation of the role of publisher as the very gesture that centers that which had been marginalized, Grahn avoids the aggrandizement of privileging the authorial self as a career. Instead, one's self-representation demands a critique of the crisis hovering within the demand for gender's ruptures within modernity to gain full access to the outcomes of print culture's ramifications. 
The decision an artist makes, to speak for women and to speak as a woman (and likewise as a member of any group, a Lesbian, a Jewish, Black, working class person, etc.) is probably the most powerful decision she will make. For in making it, she chooses autonomy, she chooses to stand somewhere in particular, to speak out to her society. Her work, in locating itself as specifically socially and historically takes on a power it cannot have if she chooses, instead, to speak anonymously, "universally." But having made this choice, she faces another danger, for if she addresses only members of her special groups, her work will have limited power, and limited integrity. It is the acknowledgement and then the inclusion of all our selves that leads us to the idea of life as consisting of many expanding, multicultural worlds in which everyone is ultimately included (as well as excluded). Grahn, 162

21 Self-publication, in fact, is the most audacious move that can be derived from the antinomian principle. The particular modernity that emerges on the West Coast is the dialogue between publishers whose belief is first and foremost in their own poetry. This is to say that a cluster of poet-editor-publishers emerged on the West Coast who were adamantly interested in what the other poet-editor-publishers were doing, and that it was to be in dialogue with these other projects that they labored so hard to keep their projects in motion.

It is in these interwoven small press projects on the West coast that we can see a stalwartly renitent example of how modernity is an insatiably heterogeneous diaspora of individual agency, clustering in communities of oppositional similitude, defiant in defeat, ever assiduous in finding another site of resistance and empowerment.

\section{BIBLIOGRAPHY}

Allmendinger, Blake, A History of California Literature, Cambridge: Cambridge University Press, 2015.

Casanova, Pascale, The World Republic of Letters, translated by Malcolm DeBevoise. Cambridge, MA: Harvard University Press, 2007.

Chartier, Roger, The Author's Hand and the Printer's Mind: Transformations of the Written Word in Early Modern Europe, Cambridge, UK ; Malden, MA: Polity Press, 2014. page 150

Finkelsein, David and Alistair McCleery. The Book History Reader. Second Edition. Routledge, 2006.

Foley, Jack, O Powerful Western Star: Poetry \& Art in California, Berkeley, CA: Pantograph Press, 2000.

Friedman, Susan Stanford, Planetary Modernism: Provocations on Modernity Across Time, New York: Columbia University Press, 2015.

Grahn, Judy, The Judy Grahn Reader. San Francisco: Aunt Lute Books, 1997.

Hitchcock, George, One Man Boat: The George Hitchcock Reader, edited by Mark Jarman, et al., Ashland, OR: Story Line Press, 2003.

Kalaidjian, Walter, American Culture Between the Wars: Revisionary Modernism and Postmodern Critique. New York: Columbia University Press, 1994. 
Klein, Norman, The History of Forgetting: Los Angeles and the Erasure of Memory. New York: Verso, 1997.

Kostelanetz, Richard, ed., A Dictionary of the Avant-Gardes, Second Edition. New York: Schirmer Books, 2000.

Maynard, John Arthur, Venice West: The Beat Generation in Southern California, Rutgers: Rutgers University Press, 1993.

McLellan, Dennis, “Noel Young, 79; Founded Independent Capra Press," LA Times, July 4, 2002. http://articles.latimes.com/2002/jul/04/local/me-young4

Nelson, W. Dale, The Imprint of Alan Swallow: quality publishing in the West. Syracuse, NY: Syracuse University Press, 2010.

Peden, Margaret Sayers, ed. Mexican Writers on Writing. Trinity University Press, 2007 (Carlos Fuentes. "A Decalogue for Writers")

Peters, Robert, The Great American Poetry Bake-Off(Second Series), Metuchen, New Jersey: Scarecrow Press, 1982.

Ross, Andrew, "The New Sentence," Marxism and the Interpretation of Culture, edited by Cary Nelson and Lawrence Gtossberg, Urbana and Chicago: University of Illinois Press, 1988.

Ruby, Jay, editor, Bohemia in Southern California, San Diego: San Diego State University Press, 2017.

Salih, al-Tayyib, Season of Migration to the North, translated by Denys Johnson-Davies,

Washington, DC: Three Continents Press, 1984.

Silverberg, Mark. The New York School Poets and the Neo-Avant-Garde: Between Radical Art and Radical Chic, Burlington, VT and Surrey, England: Ashgate, 2010.

World Cat, Advanced Search: Kayak Press, Momentum Press.

Young, Noel, "Publisher's Notes," Capra Press: A Biographical Checklist, 1969-1879, Melissa Mytinger, editor, Santa Barbara, CA: Capra Press, 1979.

\section{NOTES}

1. In The History of Forgetting, Norman Klein argues that the social imaginary is capable of generating utter illusions out of its erasures, emphasizing that "something must always be erased if something else is to protrude." (Klein, 16).

2. Darnton describes his own chart as "a communications circuit that runs from the author to the publisher (if the bookseller does not assume that role), the printer, the shipper, the bookseller, and the reader. The reader completes the circuit because he influences the author both before and after the act of composition. Authors are readers themselves." (Robert Danton, "What is the History of Books?" The Book History Reader, 11).

3. One of the major purposes of a recent anthology, Cross-Strokes: Poetry between Los Angeles and San Francisco, was to show how many poets moved between each city, thereby destabilizing the notion of two separate domains. For more background on the nationally known scene in Los Angeles and its environs, see John Arthur Maynard's Venice West, and Jay Ruby's Bohemia in Southern California.

4. The limits of this paper preclude any account of how "group identity," for instance, would bind California into a region through the emergence in the late 1960s of COSMEP (Committee of Small Press Editors and Publishers). For a brief overview, see Holdouts, pages 13-16. The other 
keywords, antagonism and avant-garde, are brought into useful focus in Mark Silverberg's assessment of Renato Poggioli's influence on the New York School of poets. "For Poggioli, antagonism is the sine qua non of the avant-garde"(Silverberg, 15).

5. I am designating these publishing projects as "independent" rather than "small press." "Small" more than hints of a dismissiveness in which one's budget determines the worth of a given project's vision.

6. Over 150 poets are interwoven in this entwined set of independent presses, the first half-dozen of which were founded between the mid-1950s and the end of the 1960s. The second half-dozen were most active between 1970 and 1985. For further information on White Rabbit and Graham Mackintosh, see Poet Be Like God, pages 112-115, 140-142, 208-209, and 309-310.

7. Marjorie Perloff's "Whose New American Poetry: Anthologizing in the 1990s" provides a thorough retrospective analysis of Allen's project. It is available on-line.

8.

Noel Young (1922-2002) wrote a short commentary on a bibliography of the books he published in which he disclaims any youthful ambitions to be a publisher. He was in his late thirties before he made the initial transition in careers. "A point I want to make, now that I see my past laid out so irrevocably on these pages, is that it wasn't my clear intention to found a publishing house. I had been happy enough designing and printing books for other independent presses (Black Sparrow, Scrimshaw, Oyez, Something Else, Christopher's Books, Unicorn, et al.) until one day I made the fatal presumption to publish a friend's poetry work under my own imprint. There, I'd done it! No trick at all. ....For the next four or five years I divided my time and energy between printing and publishing, keeping full commitment in abeyance. Here I must confess that I'd been a writer at heart and became a printer in the first place only so I could print my own stuff and peddle it from door to door. Although I never actually did, I mention this only to show a long abiding interest in books, both conceptually and physically."

9. David Harvey describes the "counter-culture" of the 1960 s as "movements (that) explored the realms of individualized self-realization through a distinctive 'new left' politics, through the embrace of anti-authoritarian gestures, iconoclastic habits (in music, dress, language and lifestyle) and the critique of everyday life." Analysis of this counter-culture all too often neglects the role of print culture in general and independent presses in particular regarding this critique of its gift exchange economy.

10. Another poet whose work also contributed to the overt protests in Inferno was Holly Beye (1922-2011). When one considers how many more independent publishers need to have their books brought into this discussion, and considers that up to this point, poets as significant as Ivan Arguelles, Sharon Doubiago, Luis Omar Salinas, Eloise Klein Healy, Jack Grapes, Christopher Buckley, and K. Curtis Lyle have not even been mentioned, one begins to realize the enormity of this undertaking. Poets who emerged out of the discourse addressed in this paper who need to be accounted for in the further development of these publishing poetics include Suzanne Lummis, Cecilia Woloch, Gail Wronsky, Joan Jobe Smith, and Fred Voss.

\section{ABSTRACTS}

Robert Darnton's communication circuit most often results in a default privileging of authors, readers, printers, and critics. This paper will examine a sequence of literary projects by West Coast publishers of poetry between 1955 and 1985 that was meant to challenge the hegemony of 
East Coast publishers. Moreover, these independent publishers aspired to establish a West Coast canon of poets as a separate and distinct roster worthy of the region being recognized as a contemporary literary capital. In often conflating the roles of publisher (as "first reader"), editor, printer, book distributor, and critic, these independent presses on the West Coast generated a critical mass of poets aligned with heterogeneous communities. In the midst of the turbulence of postmodernism, as it ever intensified, these poets made use of their juxtaposition with each other through their identification with independent publishers to reinforce their poetics in a variety of schools and movements. In particular, this paper presents detailed lists of poets in which the primary axis is their publisher(s).

Le circuit de communication proposé par Robert Darnton est un modèle qui privilégie le plus souvent les auteurs, les lecteurs, les imprimeurs et les critiques. Dans cet article sera examiné comment les éditeurs de la côte Ouest américaine se sont réunis de manière synchronique entre 1955 et 1985 autour d'un grand nombre de projets littéraires pour défier l'hégémonie des éditeurs de la côte Est et établir en même temps un canon poétique de la côte Ouest, qui octroie à la région une identité distincte en tant que capitale littéraire contemporaine. Du fait qu'ils assument à la fois les rôles d'éditeur, (comme "premier lecteur"), de directeur de publication, d'imprimeur, de distributeur et de critique, ces éditeurs indépendants de la côte Ouest ont engendré une masse critique de poètes associés à des communautés hétérogènes. À mesure que les mutations de l'époque postmoderne se sont intensifiées, sous l'impulsion des éditeurs indépendants, ces poètes ont bénéficié de leur proximité les uns avec les autres pour consolider leur œuvre au sein de différents mouvements et écoles. Cet article dresse notamment des listes de poètes dont l'axe principal est l'éditeur.

El circuito de comunicación propuesto por Robert Darnton es un modelo que suele privilegiar a los autores, lectores, impresores y críticos. En este artículo, se examina cómo los editores de la costa Oeste de los Estados Unidos se reunieron de manera sincrónica entre 1955 y 1985 alrededor de un gran número de proyectos literarios, con el fin de desafiar la hegemonía de los editores de la costa Este y al mismo tiempo establecer un canon poético de la costa Oeste, canon susceptible de otorgar a la región una identidad distinta como capital literaria contemporánea. Al asimilar a menudo los papeles de editor (como "primer lector"), director de publicación, impresor, distribuidor y crítico, esos editores independientes de la costa Oeste engendraron una masa crítica de poetas asociada a comunidades heterogéneas. Con la intensificación de las mutaciones de la época posmoderna, esos poetas aprovecharon su proximidad los unos de los otros para consolidar su obra dentro de diferentes escuelas y movimientos. Este artículo propone en particular listas de poetas cuyo eje principal es el editor.

\section{INDEX}

Mots-clés: circuit de communication, éditeurs indépendants, poètes de la côte Ouest, capitales littéraires

Palabras claves: circuito de comunicación, editores independientes, poetas de la costa Oeste de los Estados Unidos, capitales literarias

Keywords: communication circuit, independent publishers, west coast poets, literary capitals 


\section{AUTHOR}

\section{WILLIAM MOHR}

William Mohr is a professor in the Department of English at California State University, Long Beach. Hold-outs: The Los Angeles Poetry Renaissance 1948-1992 was published by the University of Iowa Press in 2011. He has had articles appear in the Journal of Beat Studies; William Carlos Williams Review; and the L.A. Review of Books. He also had a bilingual volume of his poems, Pruebas Ocultas, published in Mexico by Bonobos Editores in 2015 